\title{
COMPUTATION OF PARAMETERS OF THE PISTON MOTION IN THE TUBE UNDER THE GAS PRESSURE
}

\author{
N. S. Midonocheva, South Ural State University, Chelyabinsk, Russian Federation, \\ zeta4766@mail.ru.
}

\begin{abstract}
Mathematical models of a pneumatic system consisting of a tube closed on one side and open on the other side are under consideration. The tube has the piston that limits a certain volume of compressed gas. To find the parameters of the piston motion under pressure of the expanding gas, the mathematical model of the system is constructed in several ways: using ordinary differential equations and using partial differential equations (the equations of gas dynamics). In addition, the corresponding boundary conditions are determined. All the equations that make up the mathematical model are reduced to a dimensionless form. To perform calculations, methods of finite differences and characteristics are used. Calculations are carried out until the piston reaches the open end of the pipe or until the piston begins to slow down. Then, the results obtained with the help of the methods under consideration are compared according to the criteria of speed and accuracy. Recommendations are given on the appropriateness of using each method of constructing a mathematical model.
\end{abstract}

Keywords: mathematical model; compressed gas; pneumatic system.

\section{Introduction}

Existing methods of mathematical modeling of pneumatic systems are not totally acceptable. This is due to the fact that only some of the simplest problems can be solved applying these models for calculations by precise analytical methods. Various numerical methods are used for more complex problems. A numerical method allows to get only an approximate solution of the problem. The methods are compared with each other according to the of accuracy and speed criteria. Therefore, some methods are more preferred for solution in comparison with others. So, it is necessary to examine each method and decide which one is preferable.

In [1], a mathematical model of piston motion in the pipe taking into account the clearance between the piston and the pipe and the friction forces in the system is considered. The problem is solved using the finite difference method, using the NewtonRaphson numerical method. In [2] the problem of piston motion is solved by the method of characteristics. In [1] and [2] it is recommended to divide the solution area into sections with a small space step. This article compares the methods of solving the problem: 1) when dividing the space into parts, 2) when the gas is evenly distributed over the space. It is shown that the accuracy of the solution with the help of 1) and 2) differs by insignificantly small value.

Consider a "tube-piston" class of systems designed to create an accelerated piston motion. In general, such systems consist of two major parts: a sealed on one end cylinder which contains compressed and heated gas, and the movable piston which is driven inside the cylinder under the action of compressed air. In this case the piston speed until it reaches the end of the cylinder (the maximum speed) is crucial (Fig. 1) [3, 4]. In addition, it is necessary to take into account the possible gas heating in the process of piston motion. 


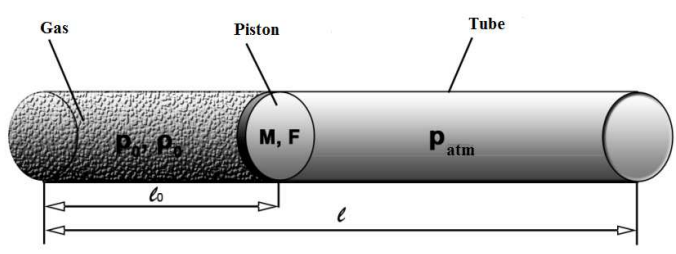

Fig. 1. The "Tube-piston" system

\section{Methodology}

1. Consider the system of equations of one-dimensional gas dynamics in Lagrange variables. The unknown functions are: $u$ (gas velocity), $\epsilon$ (deformation), $a$ (sound velocity). The equations of continuity, motion and energy equations take the following form [3-8]: The equation of continuity (compatibility)

$$
\frac{\partial \epsilon}{\partial t}=\frac{\partial v}{\partial x}
$$

- motion equation

$$
\frac{\partial v}{\partial t}-\frac{a^{2}}{\gamma \cdot(1+\epsilon)^{2}} \cdot \frac{\partial \epsilon}{\partial x}+\frac{1}{\gamma \cdot(1+\epsilon)} \cdot \frac{\partial a^{2}}{\partial x}=0
$$

- energy equation

$$
\frac{\partial a^{2}}{\partial t}+\frac{\gamma-1}{1+\epsilon} \cdot a^{2} \cdot \frac{\partial v}{\partial x}=\gamma(\gamma-1) \cdot q
$$

2. Set the initial and boundary conditions. In any section at the initial time $(t=0)$ density, pressure and temperature are the constant, and velocity and deformation are equal to zero, so

$$
\begin{gathered}
\rho(x, 0)=\rho_{0}, p(x, 0)=p_{0}, T(x, 0)=T_{0} ; \\
\epsilon(x, 0)=0, v(x, 0)=0, a(x, 0)=a_{0} .
\end{gathered}
$$

On the left end $(\mathrm{x}=0)$ gas tights to the closed end of the tube and does not move

$$
v(0, t)=0
$$

On the right end the piston moves under the influence of gas pressure and counter-pressure

$$
M v_{t}=(p-P) F .
$$

Since

$$
p=\frac{\rho_{0} a^{2}}{\gamma(1+\epsilon)},
$$

Then, for $\mathrm{x}=\mathrm{l}$ we have $\epsilon=\epsilon(l, t), v=v(l, t), a=a(l, t)$ and

$$
M \frac{\partial v}{\partial t}=\left(\frac{\rho_{0} a^{2}}{\gamma(1+\epsilon)}-P\right) \cdot F .
$$

3. Make a reduction to dimensionless form. 
Let

$$
t^{\prime}=\frac{t a_{0}}{l}, \quad x^{\prime}=\frac{x}{l}, \quad v^{\prime}=\frac{v}{a_{0}}, \quad a^{\prime}=\frac{a}{a_{0}}, \quad \mu=\frac{\rho_{0} F l}{M \gamma}, \quad \eta=\frac{P \gamma}{\rho_{0} a_{0}^{2}}, \quad q^{\prime}=\frac{q l}{a^{3}} .
$$

Equations (1)-(4) retain their form but only by $t, x, v, a, q$ we mean $t^{\prime}, x^{\prime}, v^{\prime}, a^{\prime}, q^{\prime}$. Condition (5) takes the form:

$$
\frac{\partial v}{\partial t}=\mu\left(\frac{a^{2}}{1+\epsilon}-\eta\right)
$$

After solving (1)-(4), (7) we change parameters $t, x, v, a$ to $t^{\prime}, x^{\prime}, v^{\prime}, a^{\prime}$, and then these primed parameters are replaced with the help of (6) to initial parameters $t, x, v, a$. These manipulations are performed for simplicity. Note that for $t=0$, we obtain $a=1$.

4. Introduce the finite difference method.

According to the template (Fig. 2).

$$
\begin{gathered}
\overline{\rho_{i}} \overline{u_{i}}=\rho_{i} u_{i}+\frac{\rho_{i+1} u_{i+1}+p_{i+1}-\rho_{i-1} u_{i-1}-p_{i-1}}{2 h} \cdot \tau ; \\
\overline{\rho_{i}}=\rho_{i}+\frac{\rho_{i+1} u_{i+1}+p_{i+1}-\rho_{i-1} u_{i-1}}{2 h} \cdot \tau ; \\
\overline{p_{i}}+\frac{\gamma-1}{2} \overline{\rho_{i}} \overline{u_{i}^{2}}=p_{i}+\frac{\gamma-1}{2} \rho_{i} u_{i}^{2}+\frac{\gamma \rho_{i+1} u_{i+1}+\frac{\gamma-1}{2} p_{i+1} u_{i+1}^{3}-\gamma \rho_{i-1} u_{i-1}-\frac{\gamma-1}{2} p_{i-1} u_{i-1}^{3}}{2 h} \cdot \tau .
\end{gathered}
$$

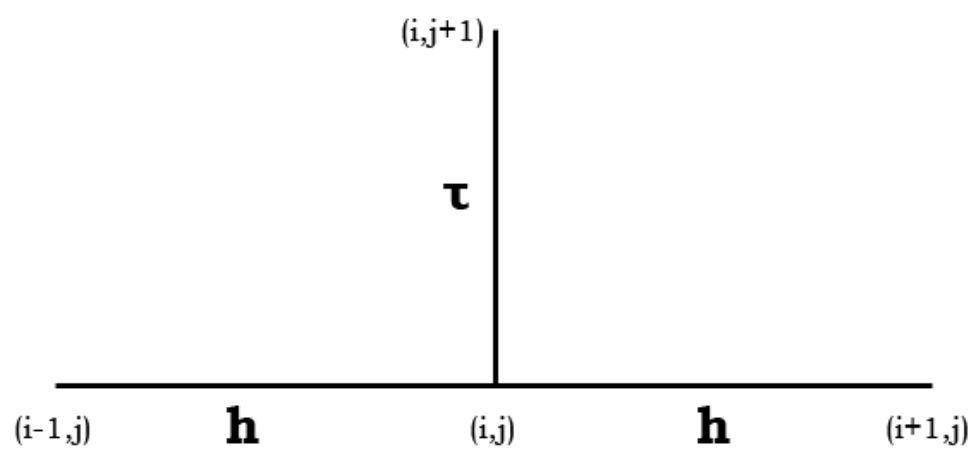

Fig. 2. Template

Recall that

$$
\beta=1+u_{x}, v=u_{t} .
$$

Considering equation of consistency, motion and Clapeyron, we obtain

$$
\frac{1}{\gamma-1} \cdot \frac{\partial}{\partial t}(p \cdot \beta)+\frac{1}{\rho_{0}} \cdot p \cdot \frac{\partial}{\partial t} \cdot \beta=q \cdot \nu+q s,
$$

or by differentiating the product, dividing by $\rho \cdot \beta$ and collecting terms, we obtain

$$
\frac{\gamma}{\beta} \cdot \frac{\partial \beta}{\partial t}+\frac{1}{p} \cdot \frac{\partial p}{\partial t}=\frac{\left.p_{0}(q v+q s) \cdot(\gamma-1)\right)}{p \cdot \beta}
$$


Set the initial and boundary conditions. At the initial time $(t=0)$ in any section the density, pressure and temperature are constant, and the velocity and distortion are equal to zero, so

$$
\rho(x, 0)=\rho_{0}, \quad p(x, 0)=p_{0}, \quad v(x, 0)=0, \quad \beta(x, 0)=1 .
$$

On the left end $(\mathrm{x}=0)$ gas tights to the closed end of the tube and does not move

$$
v(0, t)=0
$$

On the right end $\left(x=l_{0}\right)$ the piston moves under the influence of gas pressure and counter-pressure. Therefore, when $x=l_{0}$ we have $\beta=\beta\left(l_{0}, t\right), v=v\left(l_{0}, t\right), p=p\left(l_{0}, t\right)$ and

$$
M v_{t}=(p-P) \cdot F
$$

Make a reduction to dimensionless form

Let

$$
a_{0}=\sqrt{\gamma \frac{p_{0}}{\rho_{0}}}
$$

Assuming that

$$
\begin{gathered}
t^{\prime}=\frac{t a_{0}}{l_{0}}, \quad x^{\prime}=\frac{x}{l}, \quad v^{\prime}=\frac{v}{a_{0}}, \quad p^{\prime}=\frac{p}{p_{0}} \\
\mu=\frac{\rho_{0} \cdot F \cdot l_{0}}{M \cdot \gamma}, \quad P^{\prime}=\frac{P}{p_{0}}, \quad q^{\prime}=\frac{q \cdot l_{0} \gamma \cdot \gamma-1}{a_{0}^{3}}, \quad q s^{\prime}=\frac{q s \cdot l_{0} \gamma \cdot \gamma-1}{a_{0}^{3}} .
\end{gathered}
$$

Now by $t, x, v, p, q$, qs we mean $t^{\prime}, x^{\prime}, v^{\prime}, p^{\prime}, q^{\prime}, q s^{\prime}$.

In dimensionless variables we obtain

- the continuity equation:

$$
\frac{\partial \beta}{\partial t}=\frac{\partial v}{\partial x}
$$

- motion equation:

$$
\frac{\partial v}{\partial t}+\frac{1}{\gamma} \cdot \frac{\partial p}{\partial x}=0
$$

- energy equation:

$$
\frac{\gamma}{\beta} \cdot \frac{\partial \beta}{\partial t}+\frac{1}{p} \cdot \frac{\partial p}{\partial t}=\frac{q \cdot v+q s}{p \cdot \beta}
$$

- initial conditions $(t=0)$ :

$$
p(x, 0)=1, \quad v(x, 0)=0, \quad \beta(x, 0)=1,
$$

- conditions on the bottom of the tube $(x=0)$ :

$$
v(0, t)=0,
$$

- conditions on the right end of piston takes the form $(x=1)$ :

$$
\frac{\partial v}{\partial t}=\mu \cdot(p-\eta)
$$


After solving (1)-(4), (7) it is necessary to replace parameters $t, x, v, p$ by $t^{\prime}, x^{\prime}, v^{\prime}, p^{\prime}$, and then the "primed" parameters using equations (8) must be replaced by the initial parameters $t, x, v, a$ again. These manipulations are performed for simplicity purposes.

Comment. Let

$$
g(t)=\int_{0}^{t} \frac{q(\tau) \cdot v(\tau)+q s(\tau)}{p(\tau) \cdot \beta(\tau)} d \tau .
$$

Move to quadratures in equation (3). We get

$$
p=p_{0}\left(\frac{\beta_{0}}{\beta}\right)^{\gamma} \cdot e^{g(t)} .
$$

Making some rearrangement of the factors, we obtain the representation

$$
p=\int_{0}^{t} \frac{q(\tau) \cdot v(\tau)+q s(\tau)}{\beta(\tau)} d \tau .
$$

\section{Results}

The mathematical model has been constructed with the help of ordinary differential equations, based on Newton's second law, ideal gas law and Poisson adiabatic equation [9-10]:

$$
x^{\gamma} \frac{d^{2} x}{d t^{2}}=1
$$

and initial condition: if $x=l_{0}, \frac{d x}{d t}=0$. Where $x^{1}, x^{2}, x^{3}$ are motion coordinates of the piston in space, $t$ is time, $\gamma=\frac{c_{p}}{c_{v}}=\frac{i+2}{i}, i$ is the number of degrees of freedom of the molecule, $c_{p}$ and $c_{v}$ are heat capacities of a unit mass of gas at constant pressure and constant volume respectively [9].

The mathematical model constructed with the help of partial differential equations is based on the equations of gas dynamics [11-16]:

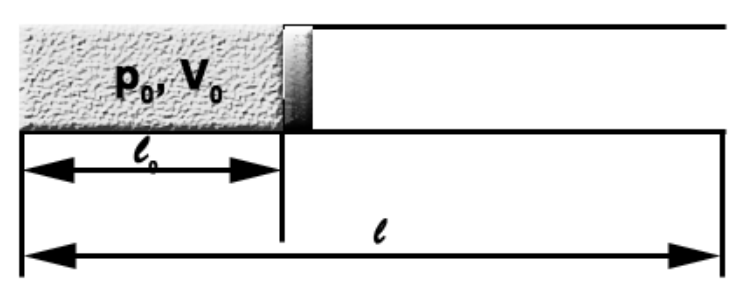

Fig. 3. The pneumatic system

- the continuity equation:

$$
\frac{\partial}{\partial t} \rho+\frac{\partial}{\partial x^{k}}\left(\rho u^{k}\right)=0
$$

where $\rho$ is density of gas at time $t, u$ is piston speed;

- motion equation:

$$
\frac{\partial}{\partial t}\left(\rho u^{i}\right)+\frac{\partial}{\partial x^{k}}\left(\rho u^{k} u^{i}\right)+\frac{\partial}{\left(\partial x^{i}\right)}=0
$$


where $p$ is the pressure of gas at time $t$;

- energy equation:

$$
\frac{\partial}{\partial t}\left(p+\frac{\gamma-1}{2} \cdot \rho \cdot u^{2}\right)+\frac{\partial}{\partial x^{k}}\left(\gamma \cdot p \cdot u^{k}+\frac{\gamma-1}{2} \cdot \rho \cdot u^{k} \cdot u^{2}\right)=0
$$

with boundary conditions: when $x=0$ the gas and the piston are at rest, so $u=0$ (Fig. 3); when $x=l$, in accordance with Newton's second law:

$$
M \frac{\partial^{2} u}{\partial t^{2}}=p F-p_{a t m} F
$$

Comparison of mathematical models which are based on ODE and the equation of gas dynamics was made. The solution obtained using gas dynamics equation is more precise: the deviation from the exact analytical solutions for simple problems is not more than $0.4-$ $1.1 \%$ (whereas in the case of ordinary differential equations - to $1.2 \%$ ), but the method works slower by $3-4 \%$ (Fig. 4). Comparison of finite difference methods and method of characteristics by testing methods on different sets of data, shows that the difference between solutions using these methods is $1-1.1 \%$. Comparison of mathematical models based on ODE and the equations of gas dynamics with gas heating (heating $2 e+07 \mathrm{~J} / \mathrm{kg}$ ) was also made. The solution obtained using ordinary differential equations: the time 0.00240744 seconds, deformation 11.5002 path $0.500009 \mathrm{~m}$, speed $235.899 \mathrm{~m} / \mathrm{sec}$., pressure $1.65846 \mathrm{~atm}$. The average time of method operation is 0.06 seconds.

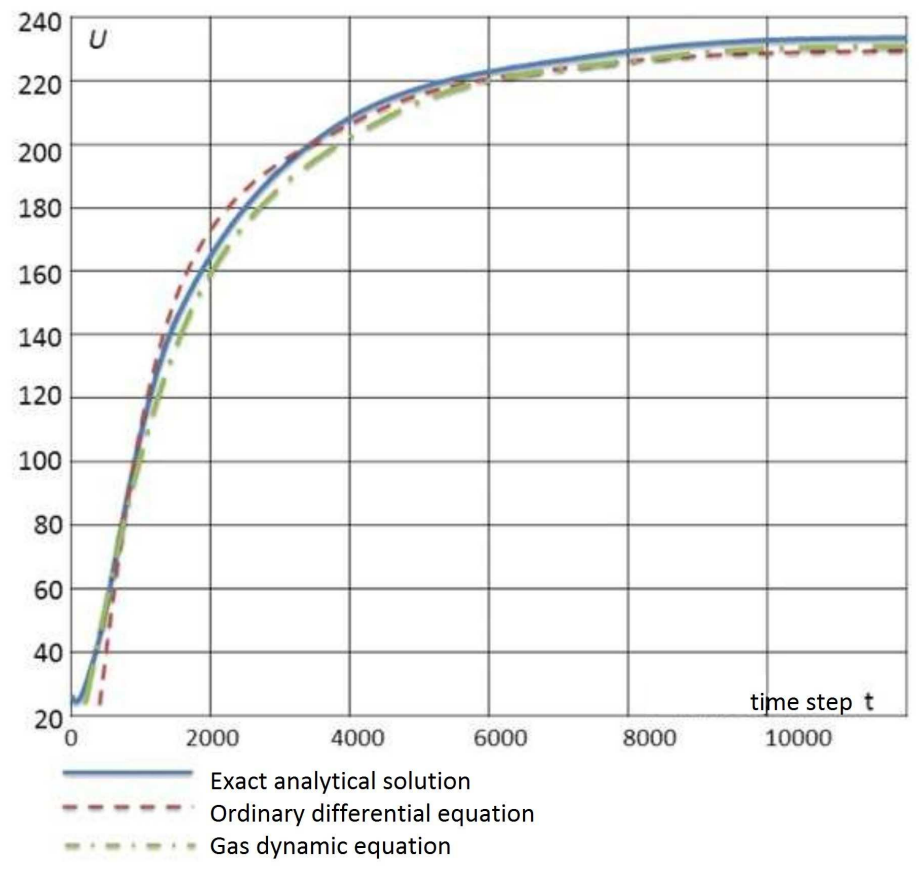

Fig. 4. Time versus the piston velocity Dependency Graph

The solution obtained using the gas dynamics equations: time 0.00240744 seconds, the deformation 11.5002, path $0.500009 \mathrm{~m}$, speed $235.899 \mathrm{~m} / \mathrm{sec}$, pressure $1.65846 \mathrm{~atm}$. The average time of method operation is 7 seconds. 
The data show that the method of gas dynamics equations allows to obtain a more precise solution of the problem and it is almost 117 times faster. The solution obtained by gas dynamics equations is slightly different in terms of accuracy $-0.02 \mathrm{~m} / \mathrm{sec}$. At the same time the finite difference method is more preferable than the method of characteristics.

I would like to thank my scientific supervisor, PhD Herreinstein A.V., for the patient guidance, encouragement and advice he has provided throughout my time as his student. The work was supported by Act 211 Government of the Russian Federation, contract № 02.A03.21.0011.

\section{References}

1. Nasibullaev I.S., Nasibullaeva E.S. Research of Different Types of Friction Forces, Arising at the Movement of the Piston in the Pipe. Scientific Achievements of Biology, Chemistry, Physics: the Collection of Articles on Materials II of the International Scientific and Practical Conference "Natural Sciences: Current Issues and Trends", Novosibirsk, on November 30, 2011. Novosibirsk, SibAK Publ., 2011, pp. 98-102. (in Russian).

2. Kleiman Ya.Z. Some Features of Mixes Movement. Acoustic Journal, 1959, vol. 5, no. 2, pp. 157-165. (in Russian).

3. Zharovtsev V.V. On a Homogeneous Difference Scheme of One-Dimensional Gas Dynamics. Russian Physics Journal,2011, vol. 54, no. 10 (2), pp. 58-60. (in Russian).

4. Golubyatnikov A.N. Integral Inequalities in Problems of Gas Dynamics. Aeromechanics and Gas Dynamics, 2001, no. 1, pp. 74-81. (in Russian).

5. Kushner E.N. Normal Forms of Some Gas Dynamics Equations. Scientific Bulletin of the Moscow State Technical University of Civil Aviation, 2013, no. 194, pp. 20-23. (in Russian).

6. Bautin S.P., Obukhov A.G. A Single Exact Stationary Solution of the Gas Dynamics Equations System. Higher Educational Institutions News. Oil and Gas, 2013, no. 4, pp. 81-86. (in Russian).

7. Rylov A.I. The Functional Relationship Between the Conservation Laws of Gas Dynamics Corresponding to the Separation of Variables. Reports of the Academy of Sciences, 2014, vol. 454, no. 6, pp. 647-650. (in Russian). doi: 10.7868/S0869565214060073.

8. Galkin V.M. An Example of the Exact Solution and Test Calculations for OneDimensional Stationary Equations of Gas Dynamics. Mathematical Modeling, 2005, vol. 17, no. 1, pp. 3-9. (in Russian).

9. Salnikov V.D. Creating Implicit Scheme for Compressible Gas Flows Simulation. Ogarev-Online, 2014, no. 19, available at: http://journal.mrsu.ru/wpcontent/uploads/2014/07/2Salnikov-Ogarev-Onlajjn4.pdf (accessed on 8 January 2017). (in Russian).

10. Galanina A.M., Favorsky A.P. Numerical Solution for Gas Dynamics System of Equations in Lagrange Variables. Mathematical Modeling, 2012, vol. 24, no. 12, pp. 119-123. (in Russian). 
11. Bochkarev N.S. Equivalent Numerical Schemes for the First and Second Order Gas Dynamics Equations. Mathematical Modeling, 2013, vol. 25, no. 4, pp. 96-101. (in Russian).

12. Bulat P.V., Volkov K.N. One-Dimensional Gas Dynamics Problems and their Solution Based on High-Resolution Finite Difference Schemes. Scientific and Technical Journal of Information Technologies, Mechanics and Optics, 2015, vol. 15, no. 4, pp. 731-740. (in Russian).

13. Kleiman Ya. Z. Some Cases of the Motion of Binary Mixtures. Acoustic Journal, 1959, vol. 5, no. 3, pp. 301-313. (in Russian).

14. Herreinstein A.V., Kastryulina N.S. The Mathematical Model of the Piston Motion in the Tube under the Action of Gas Pressure. Prospero, 2015, no. 5 (17), pp. 134-138. (in Russian).

15. Herreinstein A.V., Midonocheva N.S., Mashrabov N. Piston Motion Mathematical Model in the Tube Influenced by Burning Gas. International Conference on Industrial Engineering, Applications and Manufacturing (ICIEAM), St. Petersburg, on May 1619, 2017. St. Petersburg, 2017. doi: 10.1109/ICIEAM.2017.8076485.

Natalya S. Midonocheva, Graduate Student, Department of Applied Mathematics and Programming, South Ural State University (Chelyabinsk, Russian Federation), zeta4766@mail.ru.

УДК 517.95:532.5+532.511

DOI: $10.14529 /$ jcem180105

\section{ВЫЧИСЛЕНИЕ ПАРАМЕТРОВ ДВИЖЕНИЯ ПОРШНЯ В ТРУБЕ ПРИ ДЕЙСТВИИ ДАВЛЕНИЯ ГАЗА}

\section{Н. С. Мидоночева}

Рассматриваются математические модели пневматической системы, состоящей из трубки, закрытой с одной стороны и открытой с другой стороны. Труба содержит поршень, который ограничивает определенный объем сжатого газа. Чтобы найти параметры движения поршня под давлением расширяющегося газа, строится математическая модель системы несколькими способами: с использованием обыкновенных дифференциальных уравнений и с использованием уравнений в частных производных (уравнений газовой динамики). Кроме того, были определены соответствующие граничные условия. Также необходимо учесть, что все уравнения, составляющие математическую модель, сводятся к безразмерной форме. Расчеты выполняются с помощью методов конечных разностей и характеристик. Вычисления выполняются до тех пор, пока поршень не достигнет открытого конца трубы или пока поршень не начнет замедляться. Затем результаты, полученные с помощью рассматриваемых методов, сравниваются по критериям быстродействия и точности. Затем приводятся рекомендации относительно целесообразности использования каждого метода построения математической модели.

Ключевые слова: математическая модель; сжатый газ; пневматическая систе$\mathcal{M a}$. 


\section{Литература}

1. Насибуллаев, И.Ш. Исследование различных видов сил трения, возникающих при движении поршня в трубе / И.Ш. Насибуллаев, Э.Ш. Насибуллаева // Научные достижения биологии, химии, физики: сб. ст. по матер. II междунар. науч.-практ. конф. «Естественные науки: актуальные вопросы и тенденции развития», Новосибирск, 30 ноября 2011 г. - Новосибирск: СибАК, 2011. - С. 98-102.

2. Клейман, Я.З. Некоторые особенности движения смесей / Я.З. Клейман // Акустический журнал. - 1959. - Т. 5, № 2. - С. 157-165.

3. Жаровцев, В.В. Об одной однородной разностной схеме одномерной газовой динамики / В.В. Жаровцев // Известия высших учебных заведений. Физика. - 2011. - T. 54, № 10 (2). - C. 58-60.

4. Голубятников, А.Н. Интегральные неравенства в задачах газовой динамики / А.Н. Голубятников // Аэромеханика и газовая динамика. - 2001. - № 1. - С. 74-81.

5. Кушнер, Е.Н. Нормальные формы некоторых уравнений газовой динамики / Е.Н. Кушнер // Научный вестник Московского государственного технического университета гражданской авиации. - 2013. - № 194. - С. 20-23.

6. Баутин, С.П. Одно точное стационарное решение системы уравнений газовой динамики / С.П. Баутин, А.Г. Обухов // Известия вузов. Нефть и газ. - 2013. № 4. - C. 81-86.

7. Рылов, А.И. Функциональная зависимость между законами сохранения газовой динамики, отвечающими разделению переменных / А.И. Рылов // Доклады Академии наук. - 2014. - Т. 454, № 6. - С. 647-650.

8. Галкин, В.М. Пример точного решения и тестовые расчеты для одномерных стационарных уравнений газовой динамики / В.М. Галкин // Математическое моделирование. - 2005. - Т. 17, № 1. - С. 3-9.

9. Сальников, В.Д. Разработка неявной схемы для моделирования течений сжимаемого газа / В.Д. Сальников // Огарев-online. - 2014. № 19. - http://journal.mrsu.ru/wp-content/uploads/2014/07/2Salnikov-OgarevOnlajjn4.pdf (дата обращения: 8 января 2017 г.).

10. Галанина, А.М. Численное решение уравнений газовой динамики в лагранжевых переменных / А.М. Галанина, А.П. Фаворский // Математическое моделирование. - 2012. - Т. 24, № 12. - С. 119-123.

11. Бочкарев, Н.С. Эквивалентные разностные схемы для уравнений газовой динамики первого и второго порядков / Н.С. Бочкарев // Математическое моделирование. - 2013. - Т. 25, № 4. - С. 96-101.

12. Булат, П.В. Одномерные задачи газовой динамики и их решение при помощи разностных схем высокой разрешающей способности / П.В. Булат, К.Н. Волков // Научно-технический вестник информационных технологий, механики и оптики. 2015. - T. 15, № 4. - С. 731-740.

13. Клейман, Я.З. Некоторые случаи движения двухкомпонентных смесей Я.3. Клейман // Акустический журнал. - 1959. - Т. 5, № 3. - С. 301-313. 
14. Геренштейн, А.В. Математическая модель движения поршня в трубе при действии давления газа / А.В. Геренштейн, Н.С. Кастрюлина // Prospero. - 2015. № 5 (17). - C. 134-138.

15. Herreinstein, A.V. Piston Motion Mathematical Model in the Tube Influenced by Burning Gas / A.V. Herreinstein, N.S. Midonocheva, N. Mashrabov // International Conference on Industrial Engineering, Applications and Manufacturing (ICIEAM), St. Petersburg, on May 16-19, 2017. - St. Petersburg, 2017.

Мидоночева Наталья Сергеевна, аспирант, кафедра прикладной математики и программирования, Южно-Уральский государственный университет (г. Челябинск, Российская Федерачия), zеta4766@mail.ru.

Поступила в редакцию 12 февраля 2018 г. 